\title{
Vulnerability or Resilience: New Work Program for Teaching Practice in China's Social Work Field in the Time of COVID-19 Epidemic
}

\author{
Peng Wang,* \\ ${ }^{1}$ School of Ethnology and Sociology, Inner Mongolia University, Hohhot, China \\ *Corresponding author. Email: wangpeng@imu.edu.cn
}

\begin{abstract}
Social work originated in Europe and the United States, and gradually rose up in developing countries in the middle of the last century. Teaching practice in social work field has always been the basis for social work to take root in the multicultural society and the localization of social work in Asia. Therefore, teaching practice is a very important part of professional social work education. The sudden outbreak of COVID-19 has a global and far-reaching impact in all areas. Although social work's different field teaching practice models have been formed in the localization process of China's social work, the applicability of existing field teaching practice models in the epidemic situation has been significantly undermined. The transformation of the model of teaching practice in social work field is inevitable. Based on the previous field teaching practice models of social work in China and taking the field teaching practice of social work in the university where the author works as an example, this paper proposes a work program of teaching practice in social work field in the time of COVID-19 epidemic.
\end{abstract}

Keywords: Social Work Field; Teaching Practice; COVID-19; Work Program

\section{INTRODUCTION}

Social work is a practical subject, which is fully reflected in social work education and social work practice. Even social work education itself is a form of social work practice. [1] Training a professional social worker in social work education requires both formal learning and professional practice, which can help students judge whether social work is their best career choice. [2] As early as the end of the 19th century, at the beginning of the development of Europe and the United States' social work, teaching practice in social work field has been an important part of professional training. By the early 21st century, social work education is not only the duty of teaching, but also a means to help social work practitioners, a combination of services and interest groups, this view has become the cornerstone of professional development of social work. [3] These duties should be pre-assigned in teaching practice in social work field.

Besides Europe and the United States, Australia, Japan and other countries gradually established social work education and practice system from the 1930s to the 1950s. [4][5] The development of social work in Hong Kong has had a profound impact on China's inland so far. Social work education in Hong Kong began in 1950, and 1980s is a period of rapid development of social work education and practice in Hong Kong. Standards of social work education in Hong Kong have been established since the 1990s, such as, the teaching practice in social work field must reach 800 hours. [6]
The development of social work education and practice in China's mainland can be traced back to the 1920s and 1940s when a group of universities such as Yanching University gradually opened social work education courses, and in the 1920s and 1930s, under the guidance of some scholars, they carried out internships related to community social work such as rural construction movement. In the 1980s, with the reconstruction of sociology discipline in universities and the establishment of China's market economy system, the demand for community social services became increasingly obvious.

With the support of the Ministry of Civil Affairs of China, social work education was restarted in the late 1980s when Peking University established the major of Social work and management. In the following three decades, social work education and practice developed rapidly in China's mainland. Nationwide, more than 300 colleges and universities have set up social work majors, and there were more than 10,000 professional social work service agencies. Social work education standards have been established in 2002. According to requirements of "the national teaching standards of the undergraduate course of colleges and universities", the teaching practice in social work field for undergraduate should be no less than 800 hours, the requirements of the social worker's professional assessment are that assistant social worker and social worker should have practical ability to analyze and solve practical problems. The above requirements demand that the undergraduate students need to be professionally competent through long-time field teaching practice. 
After 30 years of development of Social work education and practice in China's mainland, the localization of China's social work development mode first prioritized education and timely transferred to practice. To promote the reform of education and the localization of professional social work practice theory and method became an important task of social work development of China's mainland in the 2020s. [7]

\section{EXISTING TEACHING PRACTICE MODEL IN SOCIAL WORK FIELD AND NEW MEASURES IN THE TIME OF COVID-19}

\subsection{The Formation of Teaching practice Models in social work field in China}

Teaching practice in social work field is generally divided into two types: long-term practice and course practice. The long-term practice requires a student to work in a social service agency as an assistant for a period of one semester or summer vacation, etc. Course practice means that students' time is allocated to classroom learning and course practice according to the teaching arrangement. For example, students are arranged to have an internship in a social service agency for 1-2 days per week or 1-2 weeks per semester. [2] This paper aims to propose a work program of long-term practice under the influence of COVID-19.

At the beginning of this century, scholars in the field of social work have discussed the teaching model of field practice. Field teaching practice is generally typed into four models: the institution-based apprenticeship; the college-based internship; practice associated to the partnership between institutions and colleges; the integration of teaching practice. [8] The main content of field teaching practice is to establish partnerships with social welfare departments of government and professional social work organizations, excavate local resources through project cooperation, and participate in the research on social issues and the construction and development of residential communities.

In 2011, some social work scholars in China had a discussion on the issue of professional field practice education, and put forward some opinions on how to carry out professional field practice education. They emphasized learning professional knowledge and internalization value in professional field practice, and established the "practice-teaching-research" trinity teaching practice. Combining the practicality and rationality of professional field practice, social work practice is integrated into professional research and local practice. The professional field teaching practice developed under the joint supervision of schools and institutions. [9] On the basis of these discussions, the development of social work field practice has followed the following three models in the last ten years.

\subsubsection{Long-term practice based on a service project or professional service}

Professional teaching practice based on service projects has its rationality under the realistic situation of the development of Social work in China. The content of project-based teaching practice is to find the convergence point of social work intervention in accordance with social needs and professional needs. The service projects include three aspects: curriculum training project, professional internship project and social service project. The teaching practice model of "social group - project - practice base" is formed through in-depth cooperation among school, government and social work institution.

However, there are ethical dilemmas and risks in project-based teaching practice. For example, project-oriented teaching practice could deviate from the essence of field teaching practice and affect the learning effect of students. Besides, the limited role of students couldn't give consideration to the interests of service beneficiary, and there is a risk of violating the ethics of "the interests of the client first" in social work. [10]

\subsubsection{Long-term practice based on teaching practice centers or bases}

The construction of teaching practice centres or bases are the foundation of practical education of social work. The link among university, local government and institution allows practice of mechanism of innovation for social work development. Systematic field practice and student field experience have always been concerned. Therefore, increasing the number and improving the quality of professional teaching practice centres or bases and covering as many social work service fields involved in social work teaching practice as possible should be promoted.

However, the field in teaching practice centres or bases is also confronted with such problems as insufficient resources, inconsistent institutional demands and arrangements, difficulty in identifying field practice objectives, low administrative tendency and professionalization of institutions, insufficient diversification of centres' or bases' service field, and insufficient professional practice instructors and supervisors. [11] [12]

\subsubsection{Long-term practice based on professional joint supervision model}

Supervision is an important working method in social work education and practice. Establishing a positive, democratic and dialogic teaching mode of supervision 
plays a direct role in cultivating students' critical thinking and practical ability, paying attention to marginalized vulnerable groups in society and setting up social work values. [13] Joint supervision refers to the formal internship agreements signed between the social work departments and professional institutions from the same city, across the land or across the border, in which social work students are arranged or sent to institutions or communities for internship, with social work departments and professional institutions jointly provide the whole training and supervision for students.

Based on joint supervision, social work department will assign students to such developed regions in eastern China as Beijing, Shanghai, Guangzhou and Shenzhen, Hong Kong for professional social work training. Social workers and senior professional teachers will provide joint supervision to the interns. In the recent two or three years, researches about joint supervision practice also show that students made evident progress in professional cognition, personality development, professional practice experience through this kind of internship. But at the same time, the social work profession is faced with the dilemma of autonomy and professionalism. Therefore, as student interns gain the experience of professional negative cognition and marginalized experience, their willingness to engage in professional social service will also decrease. [14] [15]

To sum up, social work education has formed a relatively comprehensive practice system and diversified professional field teaching practice models in more than 30 years of development. Different teaching practice models of social work have been fully applied in social work education in colleges and universities and the effect of practical experience has been summarized. However, there are still some limitations in the previous researches and summaries of teaching practice models.

First, the professional teaching practice of social work at present still give priority to professional education system. In colleges and universities, teaching practice centres or bases give a dominant position to the arrangement of students' field practice. The subjectivity of the students to participate in practice is not obvious. And it is lack of reflective researches on teaching practice models. [16] Students' thinking on generating professional practical knowledge and reflexive practice through internship or field should be encouraged and guided, which is helpful to train students to become the future planners and practitioners of the profession of social work.

Second, the existing professional teaching practice models in social work field emphasize the perfect teaching practice system of practice centres' or bases' construction. But the reality is often difficult to well meet the teaching practice system of many conditions. For instance, it is difficult to focus on the core target of the field teaching practice, the demand of colleges and universities education reform, and the professionalization of institution, the promotion of students' professional values and the ability. Finally, The COVID-19 outbreak in 2020 brought new problems to social work professional field teaching practice. The previous field teaching practice models are difficult to cope with the new problems brought by the epidemic. Under the epidemic situation, it is urgent to discuss how to protect the basic rights of students' health and safety, and how to realize the basic requirements of students' field teaching practice and professional abilities.

\subsection{How should teaching practice in social work field be carried out in the time of COVID-19?}

Taking the school of Ethnology and Sociology of Inner Mongolia University as an example, this paper analyzes the transformation of social work practice during the time of epidemic. The teaching practice plays an important role in the teaching and training scheme of social work discipline in Inner Mongolia University. The teaching practice model of social work in Inner Mongolia University mainly focuses on project practice, laboratory construction and practice. With the expansion of the field teaching practice, the construction of teaching practice centres or bases such as linking social service institutions has made significant breakthroughs. So far, diversification of centres or bases have covered school social work, social work for the disabled and the elderly, the urban community social work, social work for ethnic group and nomadic areas, rural social work, medical social work, and other fields. The number of teaching practice centres or bases reached more than 20 .

Since 2016, through establishing cooperative relations with professional social work agencies in Beijing, Shanghai, Guangzhou and other regions, the school has arranged sophomores and masters of Social Work (MSW) to go to the agencies for internship or field practice in the mode of joint supervision. It can be seen that long-term practice in summer section is of great significance to the teaching practice in social work field of the school.

Due to the outbreak of COVID-19 and the relatively limited understanding of the duration and transmission route of the epidemic, it's difficult for the previous field teaching practice models to adapt to teaching practice. Therefore, how to carry out teaching practice in social work field under the epidemic situation is a common challenge for teachers and students of social work. In the time of the COVID-19 epidemic, it is urgent to overcome the difficulties, namely, to do a good job in maintaining students' physical and mental health under the guidance of the epidemic prevention and control disciplines and measures of the Ministry of Education and other education authorities, and to achieve field teaching practice goals and practical effects during the time of epidemic without lowering standards. In order to deal with the difficulties caused by the epidemic, the teaching practice in social work field model has been changed. it is very important for social work practice innovation and thinking under the epidemic situation. The following practices of teaching practice in social work field in Inner Mongolia University are being gradually improved. 


\subsubsection{Summarizing the effectiveness and shortcomings of the previous practice models, and considering how to achieve equivalent effectiveness in the epidemic situation}

In order to summarize the successful experience and difficulties of the previous practice models, quantitative research method was used to evaluate outcomes of students' field teaching practices through long-term practice in the past summer section. Through questionnaire survey, the data of social work students' field teaching practice in the past summer section is collected, and the descriptive statistical analysis and that of related variables is used to analyze the data.

\subsubsection{Assessing the needs of current field teaching practice, identifying practice target, and formulating measures that take into account the epidemic situation and field teaching practice effect}

In accordance with the requirements of epidemic prevention and control and the discipline standards, the school, field practice instructors and students should jointly discuss and formulate safety measures and practice plans for students during the epidemic. It's necessary to assess the field practice needs of social work students who will be participating in a long-term practice of summer section. The field teaching practice needs to be adapted to local conditions of students' residence. It is recommended that students take practice in residential areas and associate with local institutions for collaborative participation. Through the questionnaire survey, the data of the students' long-term practice demand in summer section were collected, and descriptive statistical analysis was conducted on the students' practice expectation. Students are encouraged to set practice targets in line with the reality, so as to equivalently achieve practice effect of internalizing professional value, testing theoretical knowledge, improving professional ability, and generating practical experience.

\subsubsection{Students' local field practice and joint online supervision}

According to the local epidemic situation, students and institutions jointly set field practice plans and completed practice tasks and text records of practice. The field practice instructor communicated with and interviewed the students to understand the impact of the epidemic situation in the students' residence and the situation of the local institutions. In view of the differences of students' practice targets, the instructors put forward the requirements on the professional value and ability of the students. Students had a dialogue and discussion with the instructors, and independently formulated field practice plans. The field teaching practice model has been changed from the former entrusted institution internship to the current cooperative, participatory cross-professional field practice. Meanwhile,senior professional social work supervisors in Beijing, Shanghai, Guangzhou and other regions were invited to conduct online supervision jointly with the school instructors to assist students in solving problems encountered during the field practice.

\subsubsection{Action research}

Process evaluation of students' practice effect is important. It is necessary to evaluate the students' field practice process through questionnaires and make the content analysis research of students' field practice text record, so as to know the achievement of students' field practice targets. According to the actual situation of the field practice and the confusion encountered by students, timely adjust the practice tasks, to find practical wisdom and knowledge to deal with the confusion.

\subsubsection{To summarize the effect of social work practice during the epidemic and promote the diversification of field teaching practice models}

The effectiveness and improvement measures of field teaching practice model achieved during the epidemic need to be assessed, as well as the significance of this model for the reform of social work education. Depending on the trend of the epidemic, educational institutions need to determine whether to continuously improve field teaching practice model. At the same time, it may be an opportunity to promote the diversification of teaching practice models of social work and the localization of social work education in China and to practice improving the quality of social welfare services.

\section{CONCLUSION}

The COVID-19 outbreak has revealed the vulnerability of human societies to infectious diseases. But life has to go on. The concept of "resilience" in social work is an affirmation of people's potential to recover from adversity. In the time of COVID-19, teaching practice in social work field still needs to show resilience. Based on the analysis of the previous practice models and the work program of the current practice models, this paper presents the potential of continuing teaching practice in social work field. It emphasizes the use of quantitative research and qualitative research methods to evaluate the effect of social work practice and evidence-based comparative research. Meanwhile, the practice knowledge of the field teaching practice is discussed in the paradigm of action research, such as maintaining students' health, assigning field practice targets and plans through multilateral negotiations, and implementing joint online supervision. It 
is hoped that the thoughts of this paper can be used as a reference for social work education and practice in the time of the epidemic.

\section{ACKNOWLEDGMENT}

This work was supported by Inner Mongolia University Teaching reform research and construction foundation (NDJG-20-18).

\section{REFERENCES}

[1] B. Teater, An Introduction to Applying Social Work Theories and Methods, 2nd Revised ed. New York: Open University Press, 2019.

[2] D. Royse, S.S. Dhooper, K. Badger, Field Instruction: A Guide for Social Work Students, 7th ed. Illinois: Waveland Press, 2017.

[3] K.A. Kendall, Council on Social Work Education: Its antecedents and first twenty years. VA: Council on Social Work Education, 2002.

[4] P. Mendes, The History of social work in Australia: a critical literature review, Australian Social Work. 58(2) (2005) 121-131. DOI: https://10.1111/j.1447-0748.2005.00197.x

[5] H. Kosei, H. Zhou, Y. Xie, Social work education in Japan, China Social Work. 4 (1998) 49-50.

https://oversea.cnki.net/KCMS/detail/detail.aspx?dbcod $\mathrm{e}=$ CJFD\&dbname $=$ CJFD9899\&filename $=$ ZSGZ199804 017\&v=MDAwNDFyQ1VSN3FmYitSdUZ5M2tXN3J QUHo3TWRMS3hGOW5NcTQ5RVk0UjhlWDFMdX hZUzdEaDFUM3FUcldNMUY=

[6] B.-Z. Liu, Experience and enlightenment of social work practice education in Hong Kong, Journal of Chongqing City Management Vocational College, 6(3) (2006) 15-17. DOI: https://10.16817/j.cnki.csglxb.2006.03.004

[7] A.W.K. Yuen-Tsang, S.-B. Wang, Reconstruction of social work education in China through transformative partnership: Case study of the 30 years' partnership between The Hong Kong Polytechnic University and Peking University, China Journal of Social Work, 13(1) (2020) 1-21. DOI: https://10.1080/17525098.2020.1714130

[8] B.-N. Shi, Social Work Field. Beijing: Social Sciences Academic Press, 2003.
[9] B.-N. Shi, H.B. Ku, L. Ma, P. Zhou, M.J. Zhang, The Field Education and Development of Social Work in China, Journal of Zhejiang Gongshang University, 109(4) (2011) 85. DOI:

https://10.14134/j.cnki.cn33-1337/c.2011.04.009

[10] Ning. Peng, Research on Ethical Dilemma of Social Work Field Based on Service Project, master's thesis, Beijing: China Youth University for Political Science, 2014.

[11] W.W. Ning, Social coordination and goal setting: interaction between multiple subjects in social work professional practice, Journal of Social Work, 6 (2013) 41-47. DOI:

https://10.3969/j.issn.1672-4828.2013.06.006

[12] C.-H. He, A Study on the Dilemma of Social Work Students in Field Practice, master's thesis, Lanzhou: Lanzhou University, 2018.

[13] J.-Z. Yao, The construction of social work supervision model in mainland China: based on critical pedagogy, Journal of East China University of Science and Technology, Social Science Edition, 3 (2010) 35-40. https://oversea.cnki.net/KCMS/detail/detail.aspx?dbcod $\mathrm{e}=$ CJFD\&dbname $=$ CJFD2010\&filename $=$ HDLS20100 3007\&v=MTQ1NTBoMVQzcVRyV00xRnJDVVI3cW ZiK1J1Rnkza1dyekpMU25IZmJHNEg5SE1ySTIGWT RSOGVYMUx1eFITN0Q=

[14] B. Yu, R.-S. Xiong, Professional identity and industry awareness: a qualitative study on effectiveness of social work students' placement in mainland China, Journal of Social Work, 2 (2017) 48-71. DOI: https://10.3969/j.issn.1672-4828.2017.02.008

[15] M.-B. Li, P.-Y. Yue, A Paradox of Professional Identity: The unexpected consequences of professional internship for social work majors: from the perspective of sociology of professions, Social Work and Management, 20(2) (2020) 49-57.

https://oversea.cnki.net/KCMS/detail/detail.aspx?dbcod $\mathrm{e}=$ CJFD\&dbname $=$ CJFDLAST2020\&filename $=$ DGYS 202002006\&v=MDAwNDFyQ1VSN3FmYitSdUZ5M2 5WYnpJSVNyU2ZiRzRITkhNclk5RllvUjhlWDFMdX hZUzdEaDFUM3FUcldNMUY=

[16] Z.-X. Xie, Reflective practice teaching mode of theory and application: take education of social work ten years in Guangdong University of Finance \& Economics as an example, Journal of Social Work, 4 (2017) 86-95. DOI: https://10.3969/j.issn.1672-4828.2017.04.007 